\title{
John Stuart Mill and the Conflicts of Equality
}

\author{
Sven Ove Hansson ${ }^{1}$ (I)
}

Received: 22 July 2020 / Accepted: 26 January 2022 / Published online: 26 February 2022

(c) The Author(s) 2022

\begin{abstract}
John Stuart Mill commented on the relationship between equality and liberty in general terms, and he also discussed the relationships between equality and four more concrete social goals: equality vs. diversity and individual spontaneity, equality vs. freedom of trade and entrepreneurial activity, equality vs. economic incentives for workpeople, and equality vs. welfare. In his more general statements he wrote off potential conflicts between equality and liberty, claiming that only those liberties that can be enjoyed by all are real liberties-or at least they are the only ones worth defending. However, in several of his more concrete discussions he gave higher priority to various liberty-related goals than to equality. This seeming contradiction can be resolved if we assume that he distinguished between valuing a liberty per se and valuing it as a means to achieve something else.
\end{abstract}

Keywords John Stuart Mill · Equality · Liberty · Freedom · Freedom of trade · Incentives $\cdot$ Malthuseanism

\section{Introduction}

John Stuart Mill is rightly known as a champion of human liberty. It is less well known that he was also an ardent proponent of equality. Although he did not write a systematic treatise on equality, he discussed it extensively in his writings on economics, women's rights, racism and slavery. "I look upon inequality as in itself always an evil," he wrote to Arthur Helps in 1847, and therefore he could "not agree with any one who would use the machinery of society for the purpose of promoting it" (Mill 1847b: 2002; cf. Mill 1869a: 261). However, equality was not the only social goal he promoted. He was also keenly aware that worthwhile political pursuits could run into conflict.

Sven Ove Hansson

soh@kth.se

1 Division of Philosophy, Royal Institute of Technology (KTH), Teknikringen 76, 10044 Stockholm, Sweden 
Conflicts between equality and other objectives were much discussed by his contemporaries. At least since the French Revolution, anti-egalitarians had made sweeping claims about the incompatibility of equality with other prominent ends, in particular liberty (Hirschman 1991; Roach 1957; Welsh 1995). Alexis de Tocqueville's two-volume work Democracy in America (1835 and 1840), extensively reviewed by Mill (Mill 1835, 1840b), discussed such potential conflicts in a fairly nuanced and also highly influential way. The discussion is still on-going, in political philosophy as well as in day-to-day politics.

Someone who is in favour of equality as one of several social ends will have use for specific and precise treatments of potential goal conflicts involving equality. Such discussions can indeed be found in Mill's writings. He never wrote a comprehensive treatment of the conflicts of equality, but he often returned to the topic. He commented on the relationship between equality and liberty in general terms, and he also discussed several potential conflicts between equality and other more concrete social goals.

Mill's views on liberty have been extensively studied and interpreted, and there is also a growing literature on his views on equality. His position on the relationship between equality and other ideals, in particular liberty, does not seem to have been at focus in previous studies. The purpose of this contribution is to provide a systematic account of his views on how equality relates to liberty and other worthwhile goals.

Section 2 provides a brief summary of Mill's views on equality. Section 3 discusses the position of equality as one of several social goals promoted in his ethical and political thinking. Section 4 is devoted to Mill's general statements on the relationship between equality per se and liberty per se. The following four sections discuss his treatments of the potential conflicts between equality and other goals that he wrote extensively about: equality vs. diversity and individual spontaneity (Sect. 5), equality vs. freedom of trade and entrepreneurial activity (Sect. 6), equality vs. economic incentives for workpeople (Sect. 7), and equality vs. welfare (Sect. 8). In Sect. 9, his approaches to these various potential goal conflicts involving equality are compared in search for a consistent pattern.

\section{Mill's Egalitarianism}

Mill had a strong belief in the equality of all human beings (Morales 1996; Varouxakis 1998). He was strongly influenced by the enlightenment view that all humans have the same inborn abilities and capabilities. This was a view propounded for instance by Thomas Hobbes (1651: 69), Adam Smith (1776: 28-29) and, even more importantly, his father James Mill. In his Autobiography, he strongly endorsed his father's views in this regard (Mill 1873a: 109-111), and further explained why he considered this to be important:

I have long felt that the prevailing tendency to regard all the marked distinctions of human character as innate, and in the main indelible, and to ignore the irresistible proofs that by far the greater part of those differences, whether 
between individuals, races, or sexes, are such as not only might but naturally would be produced by differences in circumstances, is one of the chief hindrances to the rational treatment of great social questions and one of the greatest stumbling blocks to human improvement. (Mill 1873a: 270)

He was strongly convinced that there is, as he wrote in an essay for his future wife, "no natural inequality between the sexes" (Mill 1832: 42). In his time this was a controversial standpoint; even many of those men who agreed with him in other issues considered this to be an extreme view. His support of the equality of women, blacks and the Irish made him an object of hate among the racists and misogynists of his time (Robson 1990; Varouxakis 2013).

Following his father, he was also convinced that " $[\mathrm{t}]$ he power of education is almost boundless", as he wrote in an essay on religion in the 1850s (Mill 1874: 409). In particular, he was assured that all human beings are able to live together with much more public spirit than in existing societies. In The Subjection of Women he wrote:

[T]he true virtue of human beings is fitness to live together as equals: claiming nothing for themselves but what they as freely concede to every one else; regarding command of any kind as an exceptional necessity, and in all cases a temporary one; and preferring, whenever possible, the society of those with whom leading and following can be alternate and reciprocal. (Mill 1869a: 294)

His ideal of education was not limited to knowledge and skills. It also had a large component of moral education. A "change of character" (Mill 1873a: 239) was needed in order to realize a future, more equal society, and this was largely a matter of education. In a review essay from 1833 he even maintained that all political revolutions (except those instigated by a foreign power) originate in a moral revolution (Mill 1833a: 118).

Like Tocqueville and many other nineteenth century thinkers, Mill believed that history has an inbuilt tendency to develop in the direction of more equality. In Utilitarianism (1861a) as well as in other works, he argued that the previous abolishment of "the distinctions of slaves and freemen, nobles and serfs, patricians and plebeians" provided a strong reason to expect "the aristocracies of colour, race, and sex" to meet the same fate (Mill 1861a: 259, cf. Mill 1835: 50, 1848: 768-769; 1865a: 325 ; 1873a: 259). He also promoted various reforms that would further equality, not least improved and accessible education. Equality between women and men was not only a goal in itself but also an important means to achieve other aspects of equality. In the present state of society, he said in The Subjection of Women, the family was "a school of despotism" where children got accustomed to the unequal relationship between their parents as a model for human relationships. A family in which the parents live as equals will instead become "a school of sympathy in equality, of living together in love, without power on one side or obedience on the other". In this way, the "moral training of mankind" would improve, making the new generations better prepared to live in a more equal society (Mill 1869a: 294-295). The desired state of society was one in which "while no one is poor, no one desires to be richer, nor 
has any reason to fear being thrust back, by the efforts of others to push themselves forward" (Mill 1848: 754).

Much of the last few decades' debates on equality in political philosophy has been devoted to the distinction between various specifications of the object of equality. What is it that an egalitarian should desire to be equal? Should the focus be on equal rights, equal resources, equal opportunities, or perhaps equal happiness? This question does not appear to have attracted Mill's attention. Apparently, he assumed that a fully equal society would require equalities of several types. Although legal rights were important, they were not enough if people lacked the resources required to make use of them. In order to make the freedom of exserfs and ex-slaves real, they had to be provided with the resources needed to live as free citizens (Mill 1862: 590; 1865b: 1066; 1865c: 1098-1099). Equality of opportunity was important, for instance all educations and professions should be open to women (Mill 1869a: 270-275), but mere opportunity was not sufficient. In Chapters on Socialism he criticized the idea of a society built on competitions in which those who fail end up in misery (Mill 1879: 713). A passage from a speech he gave at a women's suffrage meeting in 1869 serves well to illustrate how different objects of equality were combined in his political vision:

We are fighting against privilege on one side, disabilities and disqualifications on the other. We are protesting against arbitrary preferences; against making favourites of some, and shutting the door against others. We are claiming equal chances, equal opportunities, equal means of self-protection for both halves of mankind. The political suffrage, which men are everywhere demanding as the sole means by which their other rights can be secured to them, we, for the same reason, and in the name of the same principles, demand for women too. (Mill 1869d: 374)

\section{Equality as One of Several Goals}

Although Mill was a strong proponent of social equality, he also recognized that compromises with other social goals were sometimes necessary. In his too little read essay Vindication of the French Revolution of February 1848, he clarified that although equality was an important social end, it must sometimes yield to other ends:

We hold with Bentham, that equality, though not the sole end, is one of the ends of good social arrangements; and that a system of institutions which does not make the scale turn in favour of equality, whenever this can be done without impairing the security of the property which is the product and reward of personal exertion, is essentially a bad government-a government for the few, to the injury of the many. (Mill 1849a: 354)

This passage refers to the view expressed by Bentham in his Principles of the Civil Code that security is the most important object of legislation since it is needed to 
uphold the other objectives; "without security, equality itself could not endure a single day" (Bentham 1962: 302, cf. 311).

Mill repeatedly qualified his advocacy of equality with the admission that some inequalities may be necessary in order to achieve other objectives. In a parliamentary hearing in 1850 he proposed, apropos of the grievances of the working classes, that policies should "remove all inequalities that can be removed without preponderant disadvantages" (Mill 1850a: 419). In the above-mentioned letter to Arthur Helps in 1847 he set the limit at "[a]s much inequality as necessarily arises from protecting all persons in the free use of their faculties of body \& mind \& in the enjoyment of what these can obtain for them" (Mill 1847b: 2002). In Utilitarianism (1861) he maintained that everybody has "an equal claim to all the means of happiness, except in so far as the inevitable conditions of human life, and the general interest, in which that of every individual is included, set limits to the maxim; and those limits ought to be strictly construed" (Mill 1861a: 258). Notably, equality was not the only end that he treated in this way; even in his fervent anti-slavery tract The Negro Question (1850) he recognized that "freedom is not the only thing necessary for human beings" (Mill 1850b: 95).

Did Mill have a universal method or criterion for solving conflicts between equality and other social goals? One obvious candidate would be a utilitarian calculus of happiness. In Utilitarianism (1861) he endorsed the "Greatest Happiness Principle" as "the ultimate end, with reference to and for the sake of which all other things are desirable" and "the standard of morality" (Mill 1861a: 214). However, given the combined qualitative and quantitative evaluation of happiness that he propounded in the same book, it is far from clear how much guidance this principle can offer in conflicts between equality and other social goals. When discussing what would ultimately be morally right, he often used terms like "the permanent interest of the human race", which arguably further extend the scope of possible interpretations of an ultimate utilitarian criterion (Mill 1848: 223, 334, 963, 1869c: 656, 658). ${ }^{1}$

Another potential approach can be found in several text passages where Mill proposed that inequalities are only acceptable if they are to the advantage of all members of society. ${ }^{2}$ The first and arguably most clear of these passages can be found in a newspaper article on the Société des Droits de l'Homme that he published in 1834:

Society will then only be on the most desirable footing, when the proprietary class shall feel compelled to make a clear case to the world in favour of the existing institutions of society; when they shall act under an habitual sense of the necessity of convincing the non-proprietary multitude, that the existing arrangement of property is a real good to them as well as to the rich; and shall

\footnotetext{
1 In Utilitarianism, Mill also makes clear how he sees the distinction between justice and equality. Justice is a rather wide moral term, which "implies something which it is not only right to do, and wrong not to do, but which some individual person can claim from us as his moral right" (Mill 1861a: 247; cf. Mill 1861a: 249-250). Equality is an aspect or interpretation of justice, and conceptions of justice differ in what role they assign to equality (Mill 1861a: 243-244).

2 This is today conceived as a "Rawlsian" idea, but is was clearly expressed already by Nicolas de Condorcet, by whom Mill might have been inspired (Hansson 2022).
} 
feel that the most effectual way to make them think it so, is to make it more and more so in fact. (Mill 1834b: 674. Cf. Mill 1847b: 2002, 1848: 230 and 980)

However, there is no clear sign that he himself applied this criterion to the goal conflicts involving equality.

\section{Equality and Liberty in General}

On several occasions Mill discussed the relationship between liberty and equality in general terms, without reference to any particular application of the two ideals. His message, on this general level, was that there is no real conflict between equality on the one hand and liberty or freedom on the other. The reason for this was that freedoms that cannot be enjoyed by all should not be counted since they are not among the freedoms worth defending. A foreshadow of this argument can be found in an essay from 1826 on France in the early Middle Ages, where he wrote that even despotism was endurable "compared with 'liberty,' when all the liberty is for a few barons, and the mass of the people are slaves" (Mill 1826a: 32). However, it is from Mill's later years that we find the most clear expressions of this argument.

In Centralisation (1862) he sharply criticized the French economist Charles Dupont-White (1807-1878) for "confounding of the love of liberty with the love of power". This was "both a psychological error, and the worst possible moral lesson". The love of power over others was "the most evil passion of human nature", and quite the reverse of love of liberty (Mill 1862: 610).

The love of liberty, in the only proper sense of that word, is unselfish; it places no one in a position of hostility to the good of his fellow-creatures; all alike may be free, and the freedom of one has no solid security but in the equal freedom of the rest. The appetite for power is, on the contrary, essentially selfish; for all cannot have power; the power of one is power over others, who not only do not share in his elevation, but whose depression is the foundation on which it is raised. (Mill 1862: 610)

Similarly, in Utilitarianism (1861) he asserted that political improvement should make us increasingly pay regard to the interests of others, generating "in each individual a feeling of unity with all the rest; which feeling, if perfect, would make him never think of, or desire, any beneficial condition for himself, in the benefits of which they are not included" (Mill 1861a: 232). In Auguste Comte and positivism (1865) he maintained that the morally appropriate approach to personal enjoyments consists in "cultivating the habitual wish to share them with others, and with all others, and scorning to desire anything for oneself which is incapable of being so shared". Its opposite, with which it was incompatible, was "the love of domination, or superiority, for its own sake; which implies, and is grounded on, the equivalent depression of other people" (Mill 1865a: 339). As we have already seen, in Subjection of Women (1869) he affirmed that the true virtue of humans was "fitness to live together as equals: claiming nothing for themselves but what they as freely concede 
to every one else" (Mill 1869a: 294). But arguably his most forceful version of this argument can be found in a speech he held in 1870 at a meeting against the use of public funds for denominational schools:

I dare say we should be told, if it were anyone's interest to affirm it, that we are no lovers of liberty because we do not permit kings to take the liberty of hanging or guillotining people at their pleasure. But the liberty we stand up for is the equal liberty of all, and not the greatest possible liberty of one, and slavery of all the rest. There ought to be room in the world for more than one man's liberty; and there ought to be room in the world for more than one man's conscience. (Mill 1870b: 385; cf. 1870c: 613)

This argument, which only allows for liberties that can be shared by all, can be used to defuse in principle all potential conflicts between liberty and equality. It is an Alexandrian solution, which, in modern terms, settles all potential conflicts between liberty and equality by giving lexicographic priority to equality. Mill could have used it to brusquely dismiss all claims of a conflict between the two ideals. To the contrary, he took several such claims seriously, discussed them in considerable detail, and in some cases proposed solutions that would infringe on equality.

\section{Equality and Diversity}

In Mill's times, just like today, the claim that equality quenches human diversity was commonly invoked against equality between women and men, but it also appeared for instance in argumentation against the extension of suffrage to larger sections of the male population (Mosedal 1978; Sanders 1996).

Mill was a strong proponent of human diversity and individuality. He devoted a chapter in On Liberty to the importance of individuality, which he described as "one of the principal ingredients of human happiness, and quite the chief ingredient of individual and social progress" (Mill 1859: 261). He also praised the "remarkable diversity of character and culture" in Europe, and maintained that Europe was "wholly indebted to this plurality of paths for its progressive and many-sided development” (Mill 1859: 274).

For good reasons, Mill saw liberty in the choice of life-styles and activities as a necessary condition for human diversity, which is why he wrote extensively on diversity in his essay on liberty. But diversity involves more than liberty, and he discussed it as a separate topic in at least three contexts: political democracy, the organization of industrial production, and the liberation of women. Notably, these three topics were all speculative to an extent that we as modern readers may need to be reminded of. He could not refer to any large-scale practical experiences of political democracy, non-capitalist enterprises or liberated women. He was writing on "the principles of individual freedom and political and social equality, as realized in institutions which as yet exist nowhere, or exist only in a rudimentary state" (Mill 1840a: 134).

In Mill's lifetime, both the opponents and the (mostly marginalized) proponents of democracy saw it as an expression, often the major expression, of equality. For 
instance, in his second review of Tocqueville's Democracy in America, Mill interprets Tocqueville as using the term "democracy" to mean equality. "By Democracy, M. de Tocqueville understands equality of conditions; the absence of all aristocracy, whether constituted by political privileges, or by superiority in individual importance and social power." Consequently, democracy in this sense was compatible with unfree institutions; it "may be equal freedom, or equal servitude." (Mill 1840b: 159) Discussants who rejected equality in favour of liberty often did so as part of their argumentation against democracy, which they considered to be incompatible with liberty. For example, in 1857 the influential Scottish jurist James Lorimer (1818-1890) defined "democracy" as "a political equality of all citizens". He further claimed that every instance of democracy was "the government of a class (the tyranny of the many) and as such, being inconsistent with the individual freedom of action of the whole body of the people, was destructive to permanence and progress alike" (Lorimer 1857: 133-134). ${ }^{3}$

Mill did not take these worries about possible negative effects of a future democratic system lightly. In On Liberty he emphasized that "[t]he limitation... of the power of government over individuals loses none of its importance when the holders of power are regularly accountable to the community" (Mill 1859: 219). Protection was needed not only against legal suppression but also against "the tyranny of the prevailing opinion and feeling; against the tendency, of society to impose, by other means than civil penalties, its own ideas and practices as rules of conduct on those who dissent from them" (Mill 1859: 220). He also saw a risk that human diversity might decrease as a byproduct of desirable social changes, such as increased education, which "brings people under common influences" (Mill 1859: 274) and improved means of communication, which would increase the exchange of information and ideas between distant places (Mill 1859: 275). The combination of these and other causes had impacts "hostile to Individuality", which had to be resisted (Mill 1859: 275). Two years later, he returned to the issue in Considerations on Representative Government, warning against the "over-government exercised by all over each" that could result in a society where "equality alone is cared for, but not liberty" (Mill 1861c: 420).

In his autobiography, Mill commented on these passages on individuality in $\mathrm{On}$ Liberty. He noted that his admonitions might appear chimerical since the ongoing social transition had "thus far been decidedly favourable to the development of new opinions, and has procured for them a much more unprejudiced hearing than they previously met with". However, he maintained that this could change in the future unless mankind became aware of the "noxious power" that a majority opinion could exert (Mill 1873a: 259-260).

In Principles of Political Economy, he discussed human diversity in relation to the organization of a future economic system. The crucial problem was, he said, how to combine two goals. One of these was an egalitarian goal, which he described on various occasions as "just distribution of the fruits of labour" (Mill 1848: xciii)

\footnotetext{
3 Other examples of the liberty argument against general suffrage can be found in Acton (1878: 64-65 and 97) and Lecky (1898: 212-214).
} 
and "a common ownership in the raw material of the globe, and an equal participation of all in the benefits of combined labour" (Mill 1873a: 239). The other was a goal of human diversity, which he referred to as "human liberty and spontaneity" (Mill 1848: 208), "personal and mental freedom" (Mill 1848: 209), and more extensively, "that multiform development of human nature, those manifold unlikenesses, that diversity of tastes and talents, and variety of intellectual points of view, which not only form a great part of the interest of human life, but by bringing intellects into stimulating collision, and by presenting to each innumerable notions that he would not have conceived of himself, are the mainspring of mental and moral progression" (Mill 1848: 209). Neither of these two goals had been realized in the society in which he lived. In particular, the goal of individual liberty and diversity was far from being satisfied in a society where most labourers "have as little choice of occupation or freedom of locomotion, are practically as dependent on fixed rules and on the will of others, as they could be on any system short of actual slavery; to say nothing of the entire domestic subjection of one half the species" (Mill 1848: 209; cf. Mill 1852b: 87).

Mill asked the question whether the two goals could be jointly achieved in a communist economy. By communism he meant "a system of community of property and equal distribution of the produce" (Mill 1848: 203-204). (The modern sense of "communism", which includes political tyranny, was unknown at this time.) Thus, by definition it satisfied one of the two goals, that of equality. However, he was worried "whether there would be any asylum left for individuality of character; whether public opinion would not be a tyrannical yoke; whether the absolute dependence of each on all, and surveillance of each by all, would not grind all down into a tame uniformity of thoughts, feelings, and actions" (Mill 1848: 209). Notably, his description of the potential problem for liberty in a communist system is quite similar to what he said about democracy, as quoted above. He conceded that "uniformity of thoughts, feelings, and actions" was "already one of the glaring evils of the existing state of society", and maintained that "the restraints of Communism would be freedom in comparison with the present condition of the majority of the human race" (Mill 1848: 209). But this was not in his view a fair comparison. Communism should not be compared to the existing capitalist system, but rather to "individual property in some form (though a form very remote from the present)" that would be better than the existing one (Mill 1848: xciii; cf. Mill 1873a: 239). He was somewhat more positive towards the Fourierist scheme, which was constructed "so that a real equality, or something more nearly approaching to it than might at first be supposed, would practically result: not, from the compression, but, on the contrary, from the largest possible development, of the various natural superiorities residing in each individual" (Mill 1848: 213). It was unknown which economic system would best combine the two goals, and it was for posterity to make that decision. In the chapter in Principles of Political Economy on a future Stationary State, he made it clear that irrespective of the economic system, in the future society he envisioned the current "trampling, crushing, elbowing, and treading on each other's heels" (Mill 1848: 754) would have to be replaced by more cooperative and equal human relations. No longer should it be a "matter of congratulation that persons who are 
already richer than any one needs to be, should have doubled their means of consuming things which give little or no pleasure except as representative of wealth". In the backward countries, he said, "increased production is still an important object", but in the advanced countries "what is economically needed is a better distribution" (Mill 1848: 755).

In his discussions of the equality between women and men, however, he did not see any conflict between on the one hand equality and on the other diversity or individuality. Instead, he emphasized that equality between the sexes would liberate women and give them opportunities to individual development that had previously been reserved for men. In his unpublished essay on marriage from 1832 or 1833 (written for his future wife) he emphasized that women could not be independent "if there be dependence in pecuniary circumstances" (Mill 1832: 42). In Subjection of Women (1869) he advocated "the equal freedom of women" (Mill 1869a: 281; cf. 1851: 456). A woman should be "entitled to choose her pursuits, urged or invited by the same inducements as any one else to interest herself in whatever is interesting to human beings, entitled to exert the share of influence on all human concerns which belongs to an individual opinion" (Mill 1869a: 327). Notably, the individual diversification among both women and men that he advocated ran contrary to the traditional, group-wise diversification between women on the one hand and men on the other. He denounced the customary differences between women and men as "eminently artificial" and forced upon women (Mill 1869a: 276). Already in A System of Logic (1843) he expressed his hopes that, in a not too distant future, an "equal freedom and an equally independent social position come to be possessed by both [women and men], and their differences of character are either removed or totally altered" (Mill 1843: 868).

In summary, Mill saw a potential conflict between equality and diversity in two of the three future, more equal, social arrangements that he discussed in detail. Both political equality (democracy) and a reorganized, more equal economic system could lead to a "tyranny" or "tyrannical yoke" of the public opinion (Mill 1859: 220; 1848: 209), potentially threatening human spontaneity and individuality. This was for him a problem to be solved by proper policies and institutional arrangements. However, in the third major egalitarian rearrangement of society that he discussed, namely equality between women and men, he did not foresee any potential conflicts with individual liberty. The reason for this difference is not entirely clear. He pointed out how prevailing inequalities suppressed women's opportunities to pursue their individual interests and inclinations; a more equal system would put an end to that suppression. But he also emphasized how prevailing inequalities subdued individual freedom and development among the labouring and voteless classes. Wouldn't a transformation that put them on an equal footing with their previous superiors similarly lead to more spontaneity and individual development? Mill did not explain the difference. One possible explanation may be that he was more worried about domineering opinions among the working classes than among women. 


\section{Equality and Entrepreneurial Freedom}

In 1840, in his second review of Tocqueville's book on democracy in America, Mill maintained that it was "no doubt true, that among the tendencies of commercial civilization, a tendency to the equalization of conditions is one, and not the least conspicuous" (Mill 1840b: 192; cf. Mill 1835: 50). In times when the major social conflict was that between aristocracy and the rest of society, it was not an uncommon view that capitalist development would more or less automatically result in a more equal society. For instance, Bentham had maintained that in a country with prospering agriculture, factories and commerce, there is a "continual progress towards equality", such that "large properties will be seen, without effort, without revolutions, without shock, to subdivide themselves by little and little, and a much greater number of individuals will participate in the advantage of moderate fortunes" (Bentham 1962: 313). But in 1840, this view was already old-fashioned if not outdated, and Mill does not seem to have repeated this claim in later years. Instead, he recognized the conflict between social equality and the opportunity to accumulate wealth that was generally assumed to be a crucial condition for economic development.

However, Mill's views on incentives for economic activities were more complex than the standard view of most economists. He did not consider it to be part of human nature that diligence and entrepreneurship can only flourish if they are rewarded by private wealth. This, in his view, depended on contingent habits and conventions. In the future, "[e]ducation, habit, and the cultivation of the sentiments" would create a new situation where a worker will "dig or weave for his country, as readily as fight for his country" (Mill 1873a: 239-241; cf. Mill 1865a: 341). However, in the short run, incentives appealing to self-interest would be necessary. In Principles of Political Economy he observed that a person who embarks upon a business "always exposes his capital to some, and in many cases to very great, danger of partial or total loss. For this danger he must be compensated, otherwise he will not incur it" (Mill 1848: 401). In a parliamentary hearing in 1852, Mill clarified the implications this would have for taxation:

I would make taxation bear upon that which people acquire without exertion and talent, rather than upon that which they acquire by exertion and talent. (Mill 1852a: 493)

One of his clearest expressions of the need for entrepreneurial incentives can be found in a newspaper article that was part of a series of articles published during the Irish famine in 1846-1847. In these articles, Mill developed a proposal for the creation of peasant properties on Irish waste lands, in order to make the Irish cottiers into smallholders owning their own land. On average, these properties should be of a size that would "fully occupy and amply remunerate the labour of the proprietor himself and of his family". However, they should not all be of equal size. This was because "[c]omplete equality is only a school of improvement where there is already a strong habitual sentiment of emulation" (Mill 1847a: 1025). Such a sentiment was not to be counted on in this case. To the contrary, he 
expected "too little ambition, too few wants" among the future smallholders (Mill 1847a: 1026). Therefore, they had to be inspired by examples showing them that improved life conditions were within reach. Thus encouraged, "the man of five acres should aspire to be the proprietor of ten, the man of ten to fifteen or more" (Mill 1847a: 1025). However, Parliament did not follow his proposal to give the cottiers land. Instead, as he later noted rather acidly, they "passed a Poor Law for maintaining them as paupers" (Mill 1873a: 243; cf. Mill 1849b: 21).

In spite of Mill's advocacy of free trade and entrepreneurial incentives, he considered them to be based on expediency, rather than on the strong moral principles which he invoked in favour of individual liberty. He made this abundantly clear in On Liberty:

Again, trade is a social act. Whoever undertakes to sell any description of goods to the public, does what affects the interest of other persons, and of society in general; and thus his conduct, in principle, comes within the jurisdiction of society... But it is now recognised, though not till after a long struggle, that both the cheapness and the good quality of commodities are most effectually provided for by leaving the producers and sellers perfectly free, under the sole check of equal freedom to the buyers for supplying themselves elsewhere. This is the so-called doctrine of Free Trade, which rests on grounds different from, though equally solid with, the principle of individual liberty asserted in this Essay. Restrictions on trade, or on production for purposes of trade, are indeed restraints; and all restraint, quâ restraint, is an evil: but the restraints in question affect only that part of conduct which society is competent to restrain, and are wrong solely because they do not really produce the results which it is desired to produce by them. (Mill 1859: 293)

In other words, contrary to the core liberties that he defended so strongly in other parts of On Liberty, the liberties of trade and business can legitimately be restrained when they do not produce the desired outcomes. In line with this, Mill said in Principles of Political Economy that "[w]hen private property in land is not expedient, it is unjust" (Mill 1848: 230; cf.: 1848: 228; 1870a: 672; 1840a: 157-158). In the posthumously published Chapters on Socialism he maintained that if the former owners are compensated, then "society is fully entitled to abrogate or alter any particular right of property which on sufficient consideration it judges to stand in the way of the public good" (Mill 1879: 753; cf. 1879: 73). He was also in favour of land reforms that would put an end to the old aristocratic system of land ownership (Mill 1848: 228-232; 1871a, 1873b). ${ }^{4}$ In 1865 he "would not shrink from extensive

\footnotetext{
${ }^{4}$ Like many of his contemporaries, Mill believed that societies and their inhabitants have to go through a long development before they reach a stage at which popular rule can be successful. There had been a time when the feudal system was the right mode of government in Europe; "the feudal system, with all its deficiencies, was sufficiently a government, contained within itself a sufficient mixture of authority and liberty, afforded sufficient protection to industry, and encouragement and scope to the development of the human faculties, to enable the natural causes of social improvement to resume their course" (Mill 1845a: 289). His call for an end to the aristocratic system of landed property in Britain was based on his assessment that it had since long lost its progressive role (Persky 2013). However, he believed that the colonized peoples outside of Europe were still incapable of self-rule, and best served by a colonial rule, which had much in common with feudalism, provided that it prepared them for future independence and
} 
confiscation" of the property of former slaveholders in the American South, if that was needed to "break the power of the Slaveholding oligarchy" and make sure that the freed slaves would not "remain in a state of dependence on their old masters approaching to slavery" (Mill 1865b: 1066).

Mill did not devote much text to explaining his distinction between economic and individual liberty, and some have complained that "[h]is reasons are not compelling" (Freeman 2011: 30). Clearly, entrepreneurial activity "affects the interest of other persons, and of society in general", but that also applies to freedom of speech and association, to which he assigned strong protection that was not contingent on expediency. Something more is needed to explain the difference. One possibility may be that he applied the principle mentioned in Sect. 4, namely that the liberties worthy of strong protection are those that can in practice be enjoyed by all (Hansson 2015). Contrary to freedom of speech and association, many of the liberties of trade and business can in practice only be enjoyed by a minority of the population.

But irrespective of how entrepreneurial freedom is justified, it tends to run into conflict with equality, and this is a conflict that Mill was acutely aware of. His solution was to promote equality to the extent that this could be done without endangering incentives to work and investment. He advocated "a system of legislation favouring equality of fortunes, so far as is consistent with the just claim of the individual to the fruits, whether great or small, of his or her own industry" (Mill 1848: 755). This may seem like a rather powerless distributional policy, but it would be far from powerless if combined with Mill's appraisal of what types of property arrangements are needed to achieve the desired incentives. In Principles of Political Economy he said:

Private property, in every defence made of it, is supposed to mean, the guarantee to individuals of the fruits of their own labour and abstinence. The guarantee to them of the fruits of the labour and abstinence of others, transmitted to them without any merit or exertion of their own, is not of the essence of the institution, but a mere incidental consequence, which, when it reaches a certain height, does not promote, but conflicts with, the ends which render private property legitimate. (Mill 1848: 208)

Based on this, he proposed that the right to inherit should be restricted by "a limitation of the sum which any one person may acquire by gift or inheritance, to the amount sufficient to constitute a moderate independence" (Mill 1848, p 755; cf.: 1831, 249; 1848: 244-245, 888; 1861b: 566-567; 1871b: 1848). According to Alexander Bain, his friend and first biographer, Mill believed that this proposal would "pull down all large fortunes in two generations" (Bain 1882: 89).

Footnote 4 (continued)

popular rule (Curtis 2009; Marwah 2011). Liberty was only for those who had been sufficiently prepared for it, thus as he said in On Liberty: "Despotism is a legitimate mode of government in dealing with barbarians, provided the end be their improvement, and the means justified by actually effecting that end" (Mill 1859: 224). 


\section{Equality and Economic Incentives for Workers}

In addition to the incentives issue for entrepreneurs, there is also the problem of how to arrange incentives for workers. There is a sharp conflict between equality and differences in wages, and therefore also between equality and the use of wage differentials to increase the quality or quantity of work outputs. From the employers' perspective, this can be described as an issue of freedom or liberty, since it concerns their freedom to use wage incentives to achieve their goals. Mill discussed the conflict between equality and incentives for workpeople in at least two contexts: wages in workers' cooperatives, and work requirements for recipients of public relief.

In Principles of Political Economy (1848) he reported that most French workers' cooperatives had originally adopted a system of "equal wages whether the work was done more or less" (Mill 1848: 782). This approach represented "a higher standard of justice" than more incentivizing wage systems such as piecework. It corresponded to "a much higher moral condition of human nature" than what was prevailing (Mill 1848: 210), and consequently it had led to losses in productivity. Therefore, most of the cooperatives had replaced it with a wage system in which everyone received "a fixed minimum, sufficient for subsistence", to which was added a remuneration based on the work being done (Mill 1848: 782). Mill saw this retreat to less equality as "a compromise with the selfish type of character formed by the present standard of morality, and fostered by the existing social institutions". As such it was "highly expedient", but only "until education shall have been entirely regenerated" (Mill 1848: 210; cf. 337).

The regeneration of education that he referred to here was no small matter. It was nothing less than the transformation from working for oneself to working for the community in a cooperative system that he was hoping for (cf. Section 6). Until that had been achieved, incentives such as wage differences were needed to keep the economy going. On several occasions, he expressed support of piecework and other arrangements that tied remuneration to the work actually performed. Most notably, in the third edition of Principles (1852) he added critical comments on a then ongoing strike by the Amalgamated Society of Engineers. The strike was officially intended to put an end to piecework and overtime, but he and many others described it as aiming at "protecting their own wages by shutting out others from access to their employment", with "almost open disregard of all other objects than high wages and little work for their own small body". Instead, he said, "it is time that the better paid classes of skilled artisans should seek their own advantage in common with, and not by the exclusion of, their fellow-labourers" (Mill 1848: 931, cf. 933-934). ${ }^{5}$ In On Liberty (1859), he repeated the criticism, denouncing a tendency among artisans to be "decidedly of opinion that bad workmen ought to receive the same wages

\footnotetext{
5 The Amalgamated Society of Engineers was indeed a union of comparatively high-paid craftsmen, and their high membership fees excluded unskilled workers. The nature of their conflict with employers in 1852 is still controversial. According to Henry Pelling (1992: 43) the conflict started "when they refused to accept an increase in the number of unskilled men in the shops". Others have affirmed the union's official standpoint that their target was the abolition of piecework and systematic overtime (Murphy 1978).
} 
as good, and that no one ought to be allowed, through piecework or otherwise, to earn by superior skill or industry more than others can without it" (Mill 1859: 287). However, four years later, in a letter to the economist Cliffe Leslie, he emphasized that taskwork would not remove the conflict of interests between employers and employees. "Nothing that I can imagine except cooperation would entirely take away the antagonism", he said, but giving the labourers a share in the profits "would go much nearer to producing identity of interest than taskwork would" (Mill 1863: 857). In his essay Endowments (1869) he returned to the topic of performancerelated pay, now proposing that the remuneration of school teachers and university professors should depend on the number of students they taught and how many of theses students passed a creditable examination (Mill 1869b: 624).

These various messages may seem inconsistent. Dale Miller (2010: 122) has indeed proposed that Mill's defence of piecework in On Liberty "must be regarded as an inconsistency on his part". However, there is a pattern in Mill's pronouncements on piecework that makes it avoidable to accuse him of inconsistency. As in other topics, he shifted between a short-term perspective in which the current state of human morality still prevails and longer-term perspectives in which human morality may have progressed (McCabe 2019). He defended piecework from the point of view of the short-term perspective, and also, as we just saw, once justified it with reference to "the selfish type of character formed by the present standard of morality". His more critical views on performance-related pay seem to be connected with a longer time perspective and a future state of human development that he was hoping for.

The poor laws were also subject to a conflict between equality and the need for economic incentives. Already in 1834 Mill endorsed the (minimally) egalitarian principle of ensuring "by a legal provision, the actual necessaries of life and health to all who cannot otherwise obtain them". In his view, this was an undeniable principle, "out of the reach of dispute by any unprejudiced person" (Mill 1834c: 686). In Principles of Political Economy he specified it further, averring that "the condition even of those who are unable to find their own support, needs not be one of physical suffering, or the dread of it, but only of restricted indulgence, and enforced rigidity of discipline" (Mill 1848: 360). The contravening principle was that in order to maintain incentives to work, allowances to the poor would have to be less attractive than employment. ${ }^{6}$ As Mill expressed it, "[i]f the condition of a person receiving relief is made as eligible as that of the labourer who supports himself by his own exertions, the system strikes at the root of all individual industry and self-government", with disastrous results for the economy (Mill 1848: 961). The combination of these two principles was a difficult equation to solve in Mill's time, since wages were often so low that they barely covered subsistence (Kurer 1989: 475-476). Mill argued that poor relief should be guaranteed, but restricted to necessities and given in exchange for labour for those able to work (Mill 1834a: 203-206; 1833b: 634-638; 1834c: 686-688; 1848: 960-962; 1850c: 43-45).

\footnotetext{
${ }^{6}$ This is a principle of incentives, but it is only indirectly related to liberty (and it certainly does not protect the liberty of the relief recipients).
} 
In both these discussions, Mill tried to strike a balance between two competing principles that he endorsed: equality in living conditions, and incentives for workpeople to work harder and better. In practice, he promoted a subsistence level for all, combined with rewards for more and better work. Notably, in his discussions of such rewards and incentives he did not refer to their realization as a matter of freedom or liberty, as others might have done, but rather as a means to achieve sufficient efficiency and productivity in the economy.

\section{Equality and Welfare}

One of the most common arguments against equality is the levelling argument. According to that argument, equality is perfectly satisfied when everyone is on the same low level, for instance when everyone is starving to the same degree. Therefore, the argument goes, equality conflicts with other goals, such as welfare. In 1852, the prominent Swedish theologian Hans Magnus Melin accused egalitarians of "preaching equality like the arsonist preaches equality when setting fire to the town; since all the houses will be of equal height when they have all been burnt to the ground" (Melin 1852: 141-142).

This argument is only relevant if directed against egalitarians who consider equality to be the only criterion of social improvement (or, at least, to have lexical priority over all other such criteria). Such egalitarians are highly uncommon figures in real life; we usually find them among the rhetorical figures of anti-egalitarian tracts. At any rate, Mill's egalitarianism certainly did not answer to that description. As we saw in Sect. 3, he stated emphatically that equality is not the only social goal. (Utilitarians are usually more vulnerable to the opposite criticism, namely that there is no room for equality in utilitarianism.) However, he had another potential problem with the relationship between equality and welfare. This was due to the fact that he was strongly influenced by Malthusian ideas, and saw the growth of human populations as a serious threat to their chances of raising themselves from poverty. He expressed these concerns in Principles of Political Economy (1848):

If all instruments of production were held in joint property by the whole people, and the produce divided with perfect equality among them, and if, in a society thus constituted, industry were as energetic and the produce as ample as at present, there would be enough to make all the existing population extremely comfortable; but when that population had doubled itself, as, with the existing habits of the people, under such an encouragement, it undoubtedly would in little more than twenty years, what would then be their condition?... If the population continued to increase at the same rate, a time would soon arrive when no one would have more than mere necessaries, and, soon after, a time when no one would have a sufficiency of those, and the further increase of population would be arrested by death. (Mill 1848: 188)

Hence, poverty was unavoidable under conditions of "perfect equality" and unchecked overpopulation. The quoted passage might give the impression that Mill shared the view of some Malthusians that the poverty of the working classes was 
unavoidable, and egalitarian reform futile (Stirati 1994). That, however, was not his position. Although Mill saw overpopulation as a serious threat, he considered it to be avoidable. A major means to avoid it was equality, in particular equality between women and men. In the same book he noted that it is "seldom by the choice of the wife that families are too numerous" (Mill 1848: 372). Reducing the number of children was in his view so urgent that legal restrictions were in principle justified to achieve it, but fortunately, this would not be necessary:

There would be no need, however, of legal sanctions, if women were admitted, as on all other grounds they have the clearest title to be, to the same rights of citizenship with men. Let them cease to be confined by custom to one physical function as their means of living and their source of influence, and they would have for the first time an equal voice with men in what concerns that function: and of all the improvements in reserve for mankind which it is now possible to foresee, none might be expected to be so fertile as this in almost every kind of moral and social benefit. (Mill 1848: 372-373)

In a letter written in 1852 , he said that putting an end to the marital "degradation \& slavery" of women was a "much more important consideration" than limiting the number of children (Mill 1852c: 88). The latter might then be seen as a by-product of the former. When writing this, Mill was aware that family size was decreasing in both Britain and France (Mill 1848: 159). He was sure that education could solve the population problem. A "well-educated labouring class" would "exercise of the same degree of habitual prudence" with respect to procreation that was "now commonly practised by the middle class" (Mill 1845b: 379). ${ }^{7}$ Education would "raise up a public opinion by which intemperance and improvidence of every kind would be held discreditable, and the improvidence which overstocks the labour market would be severely condemned, as an offence against the common weal." He did not doubt "the sufficiency of such a state of opinion, supposing it formed, to keep the increase of population within proper limits." However, "[e]ducation is not compatible with extreme poverty", and therefore "raising the entire body [of the working class] to a state of tolerable comfort" was a necessary means to achieve the level of education that would solve the population problem (Mill 1848: 375$){ }^{8}$

In this way, Mill invoked both gender equality and economic equality as remedies against the population problem. This is a remarkable reversal of the classic Malthusian argument, as condensed in the "iron law of wages", that egalitarian reform is

\footnotetext{
7 In three newspaper articles published in 1823 and 1824 (Mill 1823: 80-91, 95-97), the young Mill argued in favour of contraception, and professed to have "no belief in the efficacy of Mr. Malthus's moral check [sexual restraint], so long as the great mass of the people are so uneducated as they are at present" (ibid.: 84). In a speech in 1825 , he expressed a much more optimistic opinion on this, emphasizing that the "moral restraint" and "prudential habits" with respect to procreation that prevailed in the middle class could be expected to spread into the working classes with increasing education. This was already an ongoing process; he had "some reason to know that prudential habits are rapidly gaining ground in some of the most populous of our manufacturing districts" (Mill 1825: 304-306). In his later writings he did not discuss the means of family planning (Stack 2018).

${ }^{8} \mathrm{He}$ commented on how poverty prevents education already in a newspaper article in 1823 (Mill 1823: 89).
} 
futile due to overpopulation. Instead, said Mill, egalitarian reform is the means by which overpopulation can be conquered.

\section{Discussion}

At first sight, Mill's treatment of specific conflicts involving equality, as discussed in Sects. 5-8, may seem to be incompatible with his general approach to liberty and equality, as discussed in Sect. 4. In his more general statements, he gave a clear priority to equality, maintaining that liberties that cannot be enjoyed by all do not have much value. The remaining liberties, those that can be enjoyed by all, are compatible with equality, and thus the alleged conflict evaporates. In Sects. 5-8 we saw that he sometimes gave higher priority to various liberty-related goals than to equality. This certainly seems contradictory.

However, there is a plausible way to dissolve the seeming contradiction. For that purpose, we need to distinguish between two ways to value a liberty. A liberty can be valued per se, or as a means to something else. The following three clauses seem to reconcile Mill's various standpoints with each other:

1. Equality is one of several high-priority social goals. Compromises can be required between equality and other high-priority goals, but not between equality and goals of lower priority.

2. Liberties can only be high-priority per se if they can be enjoyed by all.

3. Liberties can be necessary means to achieve other goals which are high-priority per se.

Mill often described the necessary compromises with high-level principles as based on "expediency" (Mill 1859: 225) or "social utility" (Mill 1861a: 254). Expediency was by no means a constant factor. In particular, moral progress could remove the need for such compromises, as would be the case if new generations become willing to "dig or weave for their country", and not only for their own remuneration.

Entrepreneurship often involves power over others, for instance by hiring them to do work, and as Mill himself noted, it is not possible for everyone to have such power (Mill 1862: 610). Therefore, according to clause 2, such entrepreneurial liberty cannot be a high-priority goal per se. The same applies to extra remuneration for above-average work outputs, which can only be given to some workers. However, both of these are (incentivizing) means to achieve a goal that arguable has high priority per se, namely material welfare. This is why equality sometimes has to yield both to entrepreneurial freedoms and to work incentives, although neither of them is in itself one of the high-priority social goals. (Sects. 6 and 7).

Diversity is, at least in principle, an ideal that everyone can practice. It has high priority per se. When it appears to conflict with other high-priority social goals, such as political equality and equality in worklife, adjustments in the latter may be necessary, as Mill indicated. (Sect. 5). 
Finally, we have noted two cases in which Mill did not see any conflict but rather a synergy between equality and some other social goal. He believed that women's equality would increase social diversity, and he was also convinced that egalitarian reforms, both for women and for the working classes, would lead to improved family planning, with beneficial effects on welfare.

This reconstruction is offered in the conviction that Mill was a thoughtful enough author not to be accused of inconsistency without serious attempts to find a consistent pattern in his standpoints.

Funding Open access funding provided by Royal Institute of Technology. No specific funding for this work.

Data Availability All the data are publicly available texts.

Code Availability Not applicable.

\section{Declarations}

Conflict of interest The authors declare that they have no conflict of interest.

Open Access This article is licensed under a Creative Commons Attribution 4.0 International License, which permits use, sharing, adaptation, distribution and reproduction in any medium or format, as long as you give appropriate credit to the original author(s) and the source, provide a link to the Creative Commons licence, and indicate if changes were made. The images or other third party material in this article are included in the article's Creative Commons licence, unless indicated otherwise in a credit line to the material. If material is not included in the article's Creative Commons licence and your intended use is not permitted by statutory regulation or exceeds the permitted use, you will need to obtain permission directly from the copyright holder. To view a copy of this licence, visit http://creativecommons.org/licen ses/by/4.0/.

\section{References}

All citations of Mill refer to Mill, John Stuart, Collected Works of John Stuart Mill, 33 Volumes, ed. John M. Robson, Toronto: University of Toronto Press, 1963-1991.

Acton, John. 1878 [1907]. Sir Erskine May's democracy in Europe. In The History of Freedom and other essays, ed. John Acton, 61-100. London: Macmillan.

Bain, Alexander. 1882. John Stuart Mill. A criticism with personal recollections. London: Longmans, Green \& Co.

Bentham, Jeremy. 1962. The Works of Jeremy Bentham, ed. John Bowring |1838-1843], Volume 1. New York: Russell \& Russell.

Curtis, Michael. 2009. Orientalism and Islam. European thinkers on oriental despotism in the Middle East and India. Cambridge: Cambridge University Press.

Freeman, Samuel. 2011. Capitalism in the classical and high liberal traditions. Social Philosophy and Policy 28(2): 19-55.

Hansson, Sven Ove. 2015. Mill's circle(s) of liberty. Social Theory and Practice 41(4): 734-749.

Hansson, Sven Ove. 2022. Nicolas de Condorcet as a forerunner of John Rawls". History of European Ideas 48(1): 97-111.

Hirschman, Albert O. 1991. The rhetoric of reaction. Perversity, futility, jeopardy. Cambridge, MS: Belknap Press. 
Hobbes of Malmesbury, Thomas. 1651. Leviathan, or the matter, forme, \& power of a common-wealth ecclesiastical and civill. Andrew Crooke.

Kurer, Oskar. 1989. John Stuart Mill on government intervention. History of Political Thought 10(3): 457-480.

Lecky, William Edward Hartpole. 1896. Democracy and liberty, vol. 1. London: Longmans, Green and Co.

Lorimer, James. 1857. Political progress not necessarily democratic, or relative equality the true foundation of liberty. London: Williams and Norgate.

Marwah, Inder S. 2011. Complicating barbarism and civilization: Mill's complex sociology of human development. History of Political Thought 32(2): 345-366.

McCabe, Helen. 2019. Navigating by the North Star: The role of the 'Ideal' in John Stuart Mill's View of 'Utopian' schemes and the possibilities of social transformation. Utilitas 31(3): 291-309.

Melin, Hans Magnus. 1852. Predikningar, vol. 3. Malmö: B. Cronholm.

Mill, John Stuart. 1823 [1986]. Question of population. In Collected works, volume 22, 80-91 and 95-97.

Mill, John Stuart. 1825 [1988]. Population: Reply to Thirlwall. In Collected works, volume 26, $296-307$.

Mill, John Stuart. 1826a [1985]. Modern French historical works. Collected Works 20: 15-52.

Mill, John Stuart. 1826b [1988]. Primogeniture. Collected Works 26: 335-340.

Mill, John Stuart. 1831 [1986]. The quarterly review on the political economists. Collected Works 22: $248-250$.

Mill, John Stuart. 1832 [1984]. On marriage. Collected Works 21: 35-49.

Mill, John Stuart. 1833a [1985]. Alison's history of the French revolution. Collected Works 20: 111-122.

Mill, John Stuart. 1833b [1986]. Conduct of the Ministry with respect to the Poor Laws. Collected Works 23: 634-638.

Mill, John Stuart. 1834a [1982]. Notes on the newspapers. Collected Works 6: 149-280.

Mill, John Stuart. 1834b [1986]. French News. Collected Works 23: 670-674.

Mill, John Stuart 1834c. [1986]. The poor laws. Collected Works 23: 686-688.

Mill, John Stuart. 1835 [1977]. De Tocqueville on democracy in America. I. Collected Works 18: 47-90.

Mill, John Stuart. 1840a [1969]. Coleridge. Collected Works 10: 117-163.

Mill, John Stuart. 1840b [1977]. De Tocqueville on democracy in America. II. Collected Works 18: 153-204.

Mill, John Stuart. 1843 [1974]. A system of logic ratiocinative and inductive. Collected Works 7-8.

Mill, John Stuart. 1845a [1985]. Guizot's essays and lectures on history. Collected Works 20: 257-294.

Mill, John Stuart. 1845b [1967]. The claims of labour. Collected Works 4: 363-389.

Mill, John Stuart. 1847a [1986]. The condition of Ireland. Collected Works 24: 1024-1026.

Mill, John Stuart. 1847b [1972]. Letter to Arthur Helps, date unknown. Collected Works 17: 2000-2002.

Mill, John Stuart. 1848 [1965]. The principles of political economy. Collected Works 2-3.

Mill, John Stuart. 1849a [1985]. Vindication of the French revolution of February 1848. Collected Works 20: 317-363.

Mill, John Stuart. 1849b [1972]. Letter to Harriet Taylor, 31 March. Collected Works 14: 21-23.

Mill, John Stuart. 1850a [1967]. The savings of the middle and working classes. Collected Works 5: 405-429.

Mill, John Stuart. 1850b [1984]. The Negro question. Collected Works, 21: 85-95.

Mill, John Stuart. 1850c [1972]. Letter to Edward Herford, 22 January. Collected Works 14: 43-45.

Mill, John Stuart. 1851 [1967]. Newman's political economy. Collected Works 5: 439-457.

Mill, John Stuart. 1852a [1967]. The income and property tax. Collected Works 5: 463-498.

Mill, John Stuart. 1852b [1972]. Letter to K.D.H. Rau, 20 March. Collected Works 14: 86-87.

Mill, John Stuart. 1852c [1972]. Letter to Professor Green, 8 April. Collected Works 14: 87-89.

Mill, John Stuart. 1859 [1977]. On liberty. Collected Works 18: 213-310.

Mill, John Stuart. 1861a [1969]. Utilitarianism. Collected Works 10: 203-259.

Mill, John Stuart. 1861b [1967]. The income and property tax. Collected Works 5: 549-598.

Mill, John Stuart. 1861c [1977]. Considerations on representative goverment. Collected Works 19: 371-577.

Mill, John Stuart. 1862 [1977]. Centralisation. Collected Works 19: 579-613.

Mill, John Stuart. 1863 [1972]. Letter to T.E. Cliffe Leslie, 4 May. Collected Works 15: 857.

Mill, John Stuart. 1865a [1969]. Auguste Comte and Positivism. Collected Works 10: 261-368.

Mill, John Stuart. 1865b [1972]. Letter to Rowland G. Hazard, 7 June. Collected Works 16: 1065-1066.

Mill, John Stuart. 1865c [1972]. Letter to William Martin Dickson, 1 September. Collected Works 16: 1098-1101. 
Mill, John Stuart. 1869a [1984]. The subjection of women. Collected Works 21: 259-340.

Mill, John Stuart. 1869b [1967]. Endowments. Collected Works 5: 613-629.

Mill, John Stuart. 1869c [1967]. Thornton on Labour and its claims. Collected Works 5: 631-668.

Mill, John Stuart. 1869d [1988]. Women's suffrage. Collected Works 29: 373-381.

Mill, John Stuart. 1870a [1967]. Leslie on the land question. Collected Works 5: 669-685.

Mill, John Stuart. 1870b [1988]. The Education Bill. Collected Works 29: 381-386.

Mill, John Stuart. 1870c [1988]. Manuscript draft of "The Education Bill". Collected Works 29: 610-613.

Mill, John Stuart. 1871a [1988]. Land Tenure Reform. Collected Works 29: 416-424.

Mill, John Stuart. 1871b [1972]. Letter to John Stapleton, 25 October. Collected Works 17: 1847-1848.

Mill, John Stuart. 1873a [1981]. Autobiography. Collected Works 1: 1-290.

Mill, John Stuart. 1873b [1988]. Land Tenure Reform. Collected Works 29: 425-431.

Mill, John Stuart. 1874 [1969]. Three essays on religion. Collected Works 10: 369-489.

Mill, John Stuart. 1879 [1967]. Chapters on socialism. Collected Works 5: 703-753.

Miller, Dale E. 2010. J.S. Mill. Moral, social and political thought. Cambridge: Polity.

Morales, Maria M. 1996. Perfect equality. John Stuart Mill on well-constituted communities. Lanham, MD: Rowman \& Littlefield.

Mosedale, Susan Sleeth. 1978. Science corrupted: Victorian biologists consider the woman question. Journal of the History of Biology 11(1): 1-55.

Murphy, P.J. 1978. The origins of the 1852 lock-out in the British engineering industry reconsidered. International Review of Social History 23(2): 242-266.

Pelling, Henry. 1992. A history of British trade unionism, 5th ed. Houndmills: Palgrave MacMillan.

Persky, Joseph. 2013. Utilitarianism and luck. History of Political Economy 45(2): 287-309.

Roach, John. 1957. Liberalism and the Victorian Intelligentsia. Cambridge Historical Journal 13(1): 58-81.

Robson, John M. 1990. Mill in Parliament: The view from the Comic Papers. Utilitas 2(1): 102-143.

Sanders, Valerie. 1996. Eve's renegades: Victorian anti-feminist women novelists. London: Palgrave Macmillan.

Smith, Adam. 1776 [1976]. An Inquiry into the Nature and Causes of the Wealth of Nations. Ed. R.H. Campbell, A.S. Skinner and W.B. Todd, Oxford: Clarendon Press.

Stack, David. 2018. 'Beyond the facts': How a U.S. sociologist made John Stuart Mill into a 'Neo-Malthusian'. Historical Research 91(254): 772-790.

Stirati, Antonella. 1994. The theory of wages in classical economics. A study of Adam Smith, David Ricardo and their contemporaries. Aldershot: Edward Elgar.

Varouxakis, Georgios. 1998. John Stuart Mill on race. Utilitas 10(1): 17-32.

Varouxakis, Georgios. 2013. 'Negrophilist' Crusader: John Stuart Mill on the American Civil War and reconstruction. History of European Ideas 39(5): 729-754.

Welsh, Jennifer M. 1995. Edmund Burke and international relations: The commonwealth of Europe and the Crusade against the French revolution. Oxford: St. Martin's Press.

Publisher's Note Springer Nature remains neutral with regard to jurisdictional claims in published maps and institutional affiliations. 